\title{
The Effectiveness of Child Injury Database and Registry in Identifying Children Who are Potentially at Risk of Abuse: A Systematic Review
}

\author{
Jamaludin ANSJ'1,2*, Tan AZH¹, Heng YW¹, Low PT1ㅜ, Chua SY1, \\ Azman Hashim FS ${ }^{1}$ and Quek KF \\ 1Perdana University-Royal College of Surgeons in Ireland, Malaysia
}

Review Article

Volume 4 Issue 1

Received Date: December 13, 2018

Published Date: January 17, 2019

*Corresponding author: Dr. Anne Noor Sri Juwaneeta Jamaludin, Senior Lecturer, Perdana University-Royal College of Surgeons in Ireland, Block D, MAEPS Building, MARDI Complex, Serdang, Selangor, Malaysia, Tel: +603-8941 8646; Email: annejamaludin@perdanauniversity.edu.my

\section{Abstract}

Background: Child injury is a major cause of morbidity and mortality. The aim of this study is to systematically review trauma and injury databases and/or Child Protection Registries available globally that include children $\leq 18$ years and to determine their effectiveness in identifying children potentially at risk of abuse within the community.

Methods: Four high-yield electronic databases were searched, they were PubMed, EMBASE, PsychInfo and ProQuest to retrieve articles studying child injury databases. Full articles published in English from 2006 to 2016 that met the inclusion criteria were chosen. The included articles were appraised and evaluated by three reviewers independently.

Results: Overall, 12 articles that studied child injury databases were selected. The articles were then categorized into five themes: 1) risk factors; 2) characteristics of abused children; 3) repeated admission; 4) concordance with other databases; and 5) presentation at the emergency department. The effectiveness of each theme in identifying children who are potentially at risk of abuse was then evaluated. Injury databases that used characteristics of abused children as a theme in identifying abuse cases were shown to be the most effective, followed by risk factors (fairly effective), repeated admission (fairly effective) and concordance with other databases (fairly effective). Presentation at the emergency department was shown to be not effective in predicting child abuse.

Conclusion: Existing studies showed that there are still limitations in databases for identifying children at risk of abuse. The set-up of an integrated database with linkage to other databases will increase efficiency in detection and assist in early identification of children potentially at risk of abuse in the emergency setting.

Keywords: Child injury database; Risk of abuse; Potentially abused; Systematic review 


\section{Pediatrics \& Neonatal Biology Open Access}

Abbreviations: CPRs: Comprise Computer Patient Records; EMRs: Electronic Medical Records; MeSH: Medical Subject Heading; WA: Western Australia; ED: Emergency Department; DSW: Department of Social and Welfare; ICD-9-CM International Classification of Diseases-Ninth Revision- Clinical Modification.

\section{Introduction}

A systematic review of existing official databases that are available internationally and locally on injuries (focusing mainly on children) and evaluating their effectiveness in identifying children at risk of neglect or abuse was conducted. This systematic review addressed the broad research question: What is the availability of child injury databases and what is their effectiveness in identifying children potentially at risk of neglect or abuse. The review aimed to identify, appraise, select and synthesize all high-quality research evidence relevant to the above question [1].

Therefore, the aims of this review were to:

- Systematically review trauma and injury databases and/or Child Protection Registries that include children ages 18 years and below that are available globally;

- Determine whether these databases and registries are effective in identifying children who are potentially at risk of abuse within the community.

The systematic review process employs literature review methods to select only those studies that meet specific criteria which reasonably confirm the rigour of the 'evidence' produced by a previously published study. The primary characteristic of a systematic review is that it uses a rigorous set of criteria by which to appraise the reliability and validity of previously published research [2].

According to the Merriam-Webster dictionary, for the purpose of this study, a database was defined as "a large collection of data in a computer, organized so that it can be expanded, updated, and retrieved rapidly for various uses or known as an online database" [3]. Therefore, health databases can be in an electronic form which can comprise computer patient records (CPRs) or electronic medical records (EMRs) or disease registries or in can be in a paper-based form (hard copy).

These electronic records may be accessible in the organisation with multiple levels of user-dependent authentication [4]. As the system provides a seamless and integrated patient-specific medical history, it facilitates healthcare professionals to make better diagnosis and provide quality care services [5].
In Malaysia, there are currently 21 patient registries which covered important chronic diseases (such as diabetes, cardiovascular disease, cancer, etc.) [6]. Patient registries are considered to be important sources of information as they provide information important in the clinical setting such as; i) the natural history of a disease, ii) the clinical or cost effectiveness of specified health care products/services, iii) measuring or monitoring safety and harm of products and services; and iv) measuring the quality of care provided for the patient [6]. At least threequarter of these registries are fully funded by the Government whereas only three are funded either by private foundations/organizations or through public or individual donations. As such, these registries are not hospital-based registries.

There is evidence to suggest that many childhood abuse-related deaths are not identified as abuse prior to their deaths, further stressing the importance of early detection $[7,8]$. A registry should be an integral part of any modern surgical service. With appropriate patient privacy safeguards in place, these data can provide valuable guides for evaluation and treatment of patients at the individual level, and for program design and allocation of resources at the system level. As mentioned in the previous chapter, a registry can complement the standard indicator of child abuse and neglect (CAN) by raising the suspicion index and increasing detection rate in the clinical setting $[9,10]$.

The next sections describe the search strategy, selection criteria, findings and a comparison between the reviews.

\section{Search Strategy}

The evidence for this systematic review was obtained through searches of electronic databases for articles published in scientific journals and manually referring back to the references in those articles. The four highyield electronic databases searched were PubMed (monitored by United States National Library of Medicine), EMBASE (produced by Elsevier), PsychInfo and ProQuest.

In PubMed, PsychInfo and ProQuest the Medical Subject Heading (MeSH) terms used were: ("child" [MeSH] and ("wounds and Injuries" [MeSH] or "injuries" [MeSH] or "wounds" [MeSH] and "Database" [MeSh]). Additionally, the terms used in advanced search of EMBASE were: ("child"/exp OR child) AND ("injury"/exp OR injury) AND ("database"/exp OR database). 


\section{Pediatrics \& Neonatal Biology Open Access}

Articles that studied diseases, unintentional injuries and specific type of injuries (e.g., burns, falls and brain injuries) were excluded. Furthermore, articles of systematic review that did not provide original data and grey literature that was not formally published were also excluded. The articles that met the inclusion and exclusion criteria were then screened by three independent reviewers.

\section{Study Selection Criteria}

A set of inclusion and exclusion criteria for determining suitability of a study was outlined as below:

\section{Inclusion Criteria}

a. Studies that reviewed any aspect of child injury database or registry;

b. Target population was children ages 18 years and below;

c. Articles published in English from 2006 to 2016;

d. Full articles other than letters, reports, editorials and abstracts

\section{Exclusion Criteria}

a. Articles that studied specific diseases (rather than database/registry), unintentional injuries/child abuse and neglect and specific type of injuries (e.g., burns,

\section{falls and brain injuries)}

b. Articles of systematic review that did not provide original data;

c. Grey and unpublished literature.

Articles that met the inclusion and exclusion criteria were then screened independently by three independent reviewers. A comprehensive review of the published and grey literature on childhood injuries has been undertaken to understand the history, epidemiology and the transition in perception of unintentional and intentional injuries from the early years to current.

\section{Methods of Review}

A total of 13,170 articles were yielded from PubMed (730), EMBASE (730), PsychInfo $(11,633)$ and ProQuest (77) after applying the filters in the search. All articles were screened by title and abstract. A total of six articles from PubMed, three articles from EMBASE, and six articles from ProQuest were selected for evaluation and full texts were obtained and downloaded and saved in Zotero online (no articles were sourced from PsychInfo). These articles were combination of cumulative articles based on separate MesH headings used in the Search Strategy section.

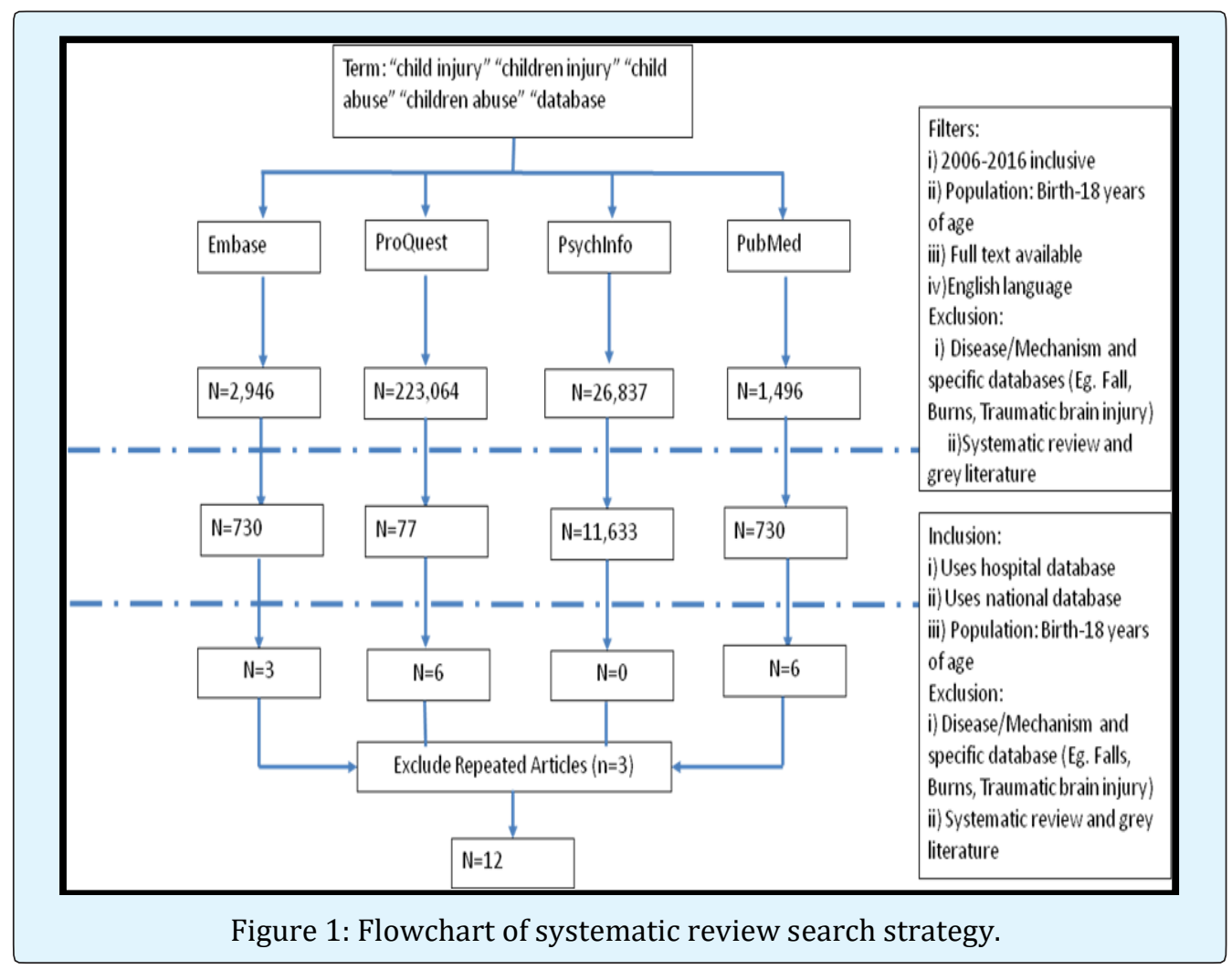




\section{Pediatrics \& Neonatal Biology Open Access}

The other articles were excluded as they were not related to the research question which addressed determining the effectiveness of child injury database/register in identifying children who are potentially at risk of abuse. At the conclusion of the selection process, 12 articles were chosen for review after excluding repeated articles. Figure 1 shows the process of extracting, reviewing and excluding the non-relevant literature.

\section{Result}

Several themes emerged and were identified across all 12 articles through analysis of injury databases to determine their effectiveness in identifying children at risk of abuse. A summary of articles included in the systematic review is shown in Table 1 below.

\begin{tabular}{|c|c|c|c|c|c|c|}
\hline No & Journal title & Author & $\begin{array}{l}\text { Database used / } \\
\text { Targeted } \\
\text { Population/Country }\end{array}$ & Summary - Important points & Themes & $\begin{array}{c}\text { Effectiveness of } \\
\text { database in } \\
\text { identifying child } \\
\text { abuse }\end{array}$ \\
\hline 1 & $\begin{array}{l}\text { A public health } \\
\text { approach to } \\
\text { child } \\
\text { maltreatment } \\
\text { surveillance: } \\
\text { Evidence from a } \\
\text { data linkage } \\
\text { project in the } \\
\text { United States }\end{array}$ & $\begin{array}{l}\text { Putnam- } \\
\text { Hornstein E, } \\
\text { Webster D, } \\
\text { Needell B, } \\
\text { Magruder J. }\end{array}$ & $\begin{array}{l}\text { Database: } \\
\text { 1999-2002 } \\
\text { 1. Vital birth records } \\
\text { (California Department of } \\
\text { Health) } \\
\text { 2. Child Protective } \\
\text { Services data } \\
\text { Population: } \\
\text { Children up to the age of } \\
5 \\
n=293,441 \\
\text { Country: } \\
\text { US }\end{array}$ & $\begin{array}{l}\text { 1. Risk factors of maltreatment by the age } \\
\text { of five } \\
\text { - Poverty ( } 22 \% \text { of children covered by } \\
\text { Medi-Cal were reported) } \\
\text { - Maternal education ( } 20 \% \text { of children } \\
\text { born to a mother with less than a high } \\
\text { school degree was reported). } \\
\text { - Children in single-parent families (about } \\
1 / 3 \text { of children with missing paternity } \\
\text { establishment). } \\
\text { - Children with a health risk at birth } \\
\text { (Nearly } 18 \% \text { identified as possible } \\
\text { victims of maltreatment). } \\
2 \text {. Almost } 1 / 3 \text { children born to black } \\
\text { mothers in California had been reported } \\
\text { to child protective services during the } \\
\text { first five years of life. } \\
3 \text {. Information gained from these record } \\
\text { linkages provides } \\
\text { - Unavailable information about the } \\
\text { characteristics of children reported to } \\
\text { child protective services. } \\
\text { - Identification of very high-risk group of } \\
\text { children who could be targeted for } \\
\text { services from the day of birth. }\end{array}$ & Risk Factors & $\begin{array}{l}\text { Effective. } \\
\text { Children potentially at } \\
\text { risk of abuse could be } \\
\text { identified based on } \\
\text { personal, familial and } \\
\text { socio-demographic } \\
\text { characteristics at } \\
\text { birth. }\end{array}$ \\
\hline
\end{tabular}




\section{Pediatrics \& Neonatal Biology Open Access}

\begin{tabular}{|c|c|c|c|c|c|c|}
\hline 2 & $\begin{array}{l}\text { The } \\
\text { epidemiology of } \\
\text { infant injuries } \\
\text { and alarming } \\
\text { health } \\
\text { disparities. }\end{array}$ & $\begin{array}{l}\text { Falcone RA Jr, } \\
\text { Brown RL, } \\
\text { Garcia VF. }\end{array}$ & $\begin{array}{l}\text { Database: } \\
1995 \text { - } 2004 \\
\text { Cincinnati Children's } \\
\text { Hospital Medical Center, } \\
\text { Cincinnati } \\
\text { Infant Injury Database } \\
\text { Population: } \\
\text { Infants (age, 28-364 } \\
\text { days) n=1270 } \\
\text { Country: } \\
\text { US }\end{array}$ & $\begin{array}{l}\text { 1. Fall is the most common mechanism of } \\
\text { injury, followed by abuse, motor vehicle } \\
\text { accident, suffocation and drowning. } \\
2 \text {. A nearly 3.5-fold increased risk of } \\
\text { death from injury for AA infants } \\
\text { compared to white infants (Consistent } \\
\text { with the known health disparities based } \\
\text { on race). } \\
\text { 3. Dissect the unique epidemiology of this } \\
\text { problem by identifying } 2 \text { particularly } \\
\text { high-risk mechanisms, abuse and } \\
\text { suffocation, which appear to be } \\
\text { contributing factors to the } \\
\text { disproportionately high mortality rate } \\
\text { among AA infants in our community. } \\
\text { 4. Significantly higher percentages of AA } \\
\text { infants were being dispositioned directly } \\
\text { to the coroner. This may be a } \\
\text { consequence of delayed presentation or } \\
\text { differences in specific injury patterns. }\end{array}$ & Risk Factors & $\begin{array}{l}\text { Fairly effective. } \\
\text { It looked at the role of } \\
\text { ethnicity in relation to } \\
\text { child injury. }\end{array}$ \\
\hline 3 & $\begin{array}{l}\text { Maternal social } \\
\text { characteristics } \\
\text { and mortality } \\
\text { from injuries } \\
\text { among infants } \\
\text { and toddlers in } \\
\text { Estonia. }\end{array}$ & $\begin{array}{l}\text { Tiikkaja S, } \\
\text { Rahu K, Koupil } \\
\text { I, Rahu M. }\end{array}$ & $\begin{array}{l}\text { Database: } \\
\text { 1992-2002 Estonian } \\
\text { Medical Birth Registry } \\
\text { with Mortality Database } \\
\text { Population: } \\
\text { Children born } 1992- \\
2002 \mathrm{n}=148521 \\
\text { Country: } \\
\text { Estonia }\end{array}$ & $\begin{array}{l}\text { 1. Children are at risk from both violence } \\
\text { and negligence of drunken parents. } \\
\text { 2. Maternal smoking is associated with an } \\
\text { increased risk for fires and injuries from } \\
\text { fire burns. } \\
\text { 3. Lower maternal education and high } \\
\text { birth order increase the risk of infant and } \\
\text { toddler injury death. } \\
\text { 4. Higher risks were also found for low } \\
\text { maternal age, unmarried, non-Estonian } \\
\text { nationality and multiplicity of pregnancy. }\end{array}$ & Risk Factors & $\begin{array}{l}\text { Fairly effective. } \\
\text { Linking mother's data } \\
\text { with child to } \\
\text { determine risk of } \\
\text { abuse. }\end{array}$ \\
\hline
\end{tabular}




\section{Pediatrics \& Neonatal Biology Open Access}

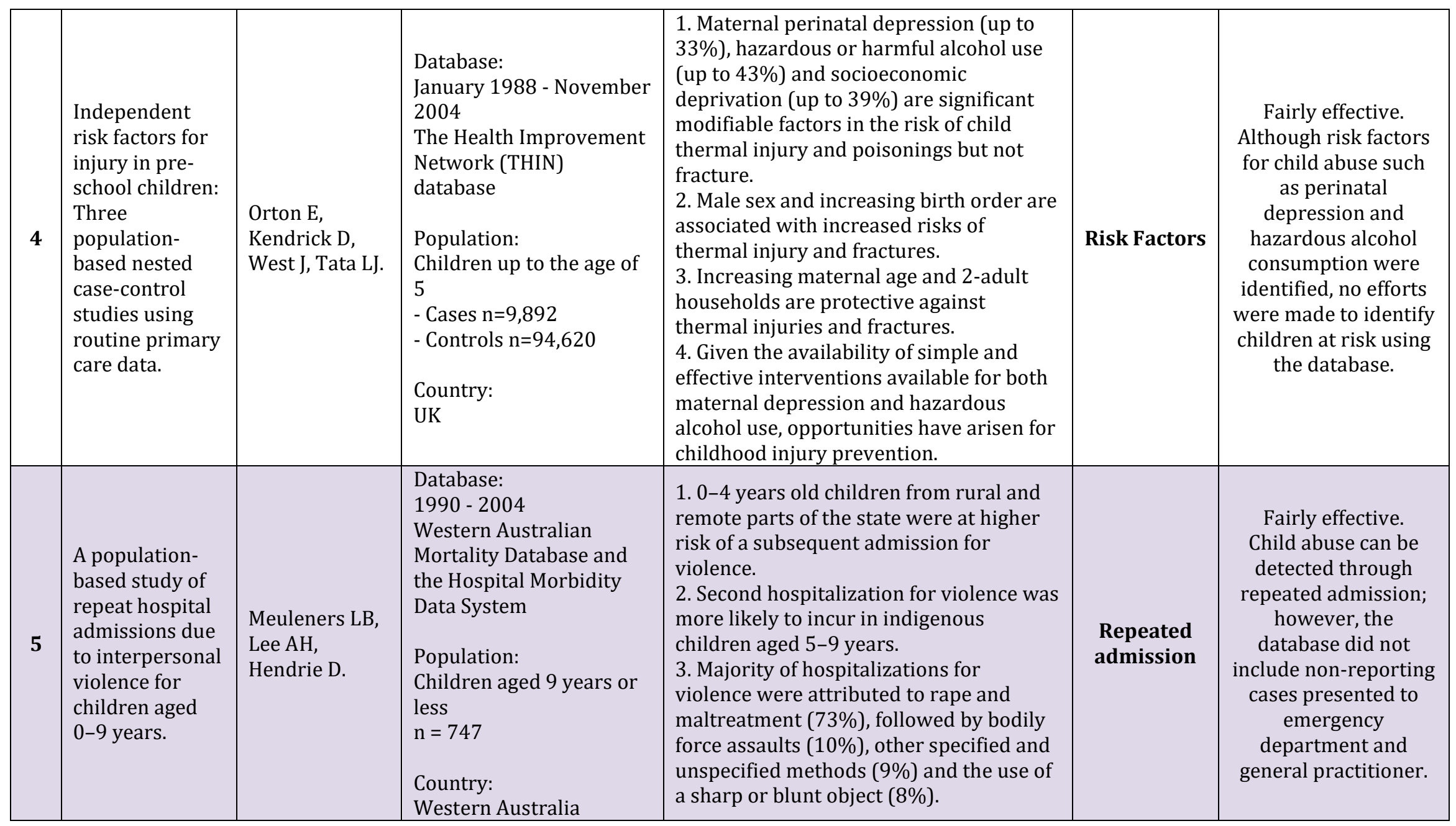




\section{Pediatrics \& Neonatal Biology Open Access}

\begin{tabular}{|c|c|c|c|c|c|c|}
\hline 6 & $\begin{array}{l}\text { The Tip of the } \\
\text { Iceberg for } \\
\text { Child Abuse: } \\
\text { The Critical } \\
\text { Roles of the } \\
\text { Pediatric } \\
\text { Trauma Service } \\
\text { and its Registry. }\end{array}$ & $\begin{array}{l}\text { Chang DC, } \\
\text { Knight V, } \\
\text { Ziegfeld S, } \\
\text { Haider A, } \\
\text { Warfield D, } \\
\text { Paidas C. }\end{array}$ & $\begin{array}{l}\text { Database: } \\
1990 \text { - } 2002 \\
\text { Urban Level I pediatric } \\
\text { trauma registry (Johns } \\
\text { Hopkins Hospital) } \\
\text { Population: } \\
\text { Children aged up to } 18 \\
\text { years } \\
n=11,919 \\
\text { Country: } \\
\text { US }\end{array}$ & $\begin{array}{l}\text { 1. Abused children were associated with } \\
\text { significant characteristics in pediatric } \\
\text { trauma service: } \\
\text { - younger (1.6 vs. } 7.0) \\
\text { - blunt injuries ( } 92.4 \% \text { vs. } 91.1 \%) \\
\text { - higher Injury Severity Score (especially } \\
\text { in head and integument) } \\
\text { - required longer lengths of stay ( } 4 \text { days } \\
\text { vs. } 1 \text { day) } \\
\text { - higher mortality rate (12\% vs. } 2 \%) \\
\text { - transferred from another institution } \\
(40.3 \%) \\
\text { 2. Fathers, step-fathers, or male partners } \\
\text { were the most common perpetrators of } \\
\text { the abuse (58.6\%). }\end{array}$ & $\begin{array}{l}\text { Characteris- } \\
\text { tics of abused } \\
\text { children }\end{array}$ & $\begin{array}{c}\text { Effective. } \\
\text { Children potentially at } \\
\text { risk of abuse showed } \\
\text { significant } \\
\text { characteristics } \\
\text { compared with non- } \\
\text { abuse cases. }\end{array}$ \\
\hline 7 & $\begin{array}{l}\text { Assessing the } \\
\text { concordance of } \\
\text { health and child } \\
\text { protection data } \\
\text { for 'maltreated' } \\
\text { and } \\
\text { 'unintentionally } \\
\text { injured' } \\
\text { children [14] }\end{array}$ & $\begin{array}{l}\text { McKenzie K, } \\
\text { Scott D, Fraser } \\
\text { JA, Dunne MP. }\end{array}$ & $\begin{array}{l}\text { Database: } \\
\text { January } 2003 \text { - December } \\
2006 \\
\text { 1. Hospital medical } \\
\text { records } \\
\text { 2. Child Protection } \\
\text { Service (CPS) database } \\
\text { Population: } \\
\text { Children aged up to } 18 \\
\text { years } \\
\mathrm{n}=884 \\
\text { Country: } \\
\text { Australia }\end{array}$ & $\begin{array}{l}\text { 1. High concordance ( } 93.1 \%) \text { between } \\
\text { hospital-coded maltreatment and known } \\
\text { CPS data. } \\
\text { 2. However, being known to the CPS was } \\
\text { not proven to prevent child } \\
\text { maltreatment, as } 85 \% \text { of maltreatment- } \\
\text { coded children already had recent CPS } \\
\text { events. } \\
3.1 / 3 \text { of children coded as unintentional } \\
\text { injury had prior CPS records, with } 11 \% \text { of } \\
\text { them having a recent CPS event } \\
\text { (predictors of linkage include prior CPS } \\
\text { documentation and superficial } \\
\text { contusions of the arms/legs). This } \\
\text { highlights the importance of considering } \\
\text { the possibly of abuse in children } \\
\text { presenting with unintentional injuries. }\end{array}$ & $\begin{array}{c}\text { Concor- } \\
\text { dance with } \\
\text { other } \\
\text { databases }\end{array}$ & $\begin{array}{l}\text { Fairly effective. } \\
\text { However the high } \\
\text { proportion of children } \\
\text { with prior CPS record } \\
\text { presenting with } \\
\text { unintentional injury } \\
\text { indicates a need for } \\
\text { better detection } \\
\text { modalities. }\end{array}$ \\
\hline 8 & $\begin{array}{l}\text { Incidence of } \\
\text { Serious Injuries } \\
\text { Due to Physical } \\
\text { Abuse in the } \\
\text { United States: } \\
1997 \text { to } 2009 .\end{array}$ & $\begin{array}{l}\text { Leventhal JM, } \\
\text { Gaither JR. }\end{array}$ & $\begin{array}{l}\text { Database: } \\
1997 \text { - } 2009 \\
\text { Kids' Inpatient Database } \\
\text { Population: } \\
\text { Children < } 18 \text { years }\end{array}$ & $\begin{array}{l}\text { 1. Over a 12-year period, the incidence of } \\
\text { hospitalized children with serious } \\
\text { injuries due to physical abuse had } \\
\text { increased slightly. } \\
\text { 2. However, these results were contrast } \\
\text { to the marked declining in substantiated }\end{array}$ & $\begin{array}{c}\text { Concor- } \\
\text { dance with } \\
\text { other } \\
\text { databases }\end{array}$ & $\begin{array}{l}\text { Fairly effective. } \\
1 . \text { The database is } \\
\text { only prepared every } 3 \\
\text { years. However, there } \\
\text { were changes in } \\
\text { coding of causes of }\end{array}$ \\
\hline
\end{tabular}




\section{Pediatrics \& Neonatal Biology Open Access}

\begin{tabular}{|c|c|c|c|c|c|c|}
\hline & & & $\begin{array}{l}\text { 1997, } \mathrm{n}=4327 \\
\text { 2000, } \mathrm{n}=4305 ; \\
\text { 2003, } \mathrm{n}=4409 ; \\
\text { 2006, } \mathrm{n}=4473 ; \\
2009, \mathrm{n}=4782 \\
\text { Country: } \\
\text { US }\end{array}$ & $\begin{array}{l}\text { physical abuse based on data from child } \\
\text { protective services. } \\
\text { 3. Challenge of using a single source of } \\
\text { data to track a complex problem such as } \\
\text { child physical abuse. }\end{array}$ & & $\begin{array}{c}\text { injuries in medical } \\
\text { documentation of } \\
\text { child abuse over time } \\
\text { This might impede } \\
\text { efforts in comparing } \\
\text { the evolution of data } \\
\text { throughout the years. } \\
\text { 2.KIDs cover all } \\
\text { pediatric conditions } \\
\text { rather than only focus } \\
\text { on child abuse. }\end{array}$ \\
\hline 9 & $\begin{array}{l}\text { Western } \\
\text { Australian } \\
\text { emergency } \\
\text { department } \\
\text { presentations } \\
\text { related to child } \\
\text { maltreatment } \\
\text { and intentional } \\
\text { injury: } \\
\text { population level } \\
\text { study utilising } \\
\text { linked health } \\
\text { and child } \\
\text { protection data. }\end{array}$ & $\begin{array}{l}\text { O'Donnell M, } \\
\text { Nassar N, } \\
\text { Jacoby P, } \\
\text { Stanley F. }\end{array}$ & $\begin{array}{l}\text { Database: } \\
2001 \text { - 2005 Western } \\
\text { Australia Emergency } \\
\text { Department data } \\
\text { Collection (EDDC): } \\
\text { Population: } \\
\text { All children aged 0-17 } \\
\text { n= 657656 } \\
\text { Country: } \\
\text { Australia }\end{array}$ & $\begin{array}{l}\text { 1. A large proportion of females had ED } \\
\text { presentations related to maltreatment } \\
\text { and examination for assault. } \\
\text { 2. Children aged less than } 1 \text { year and over } \\
12 \text { years made up a large proportion of } \\
\text { maltreatment-related ED presentations } \\
\text { as well as children from socio- } \\
\text { economically disadvantaged } \\
\text { backgrounds. } \\
\text { 3. Large proportion of Aboriginal children } \\
\text { had maltreatment ( } 24 \% \text { ) and intentional } \\
\text { injury (16\%) presentations compared } \\
\text { with the proportion of Aboriginal } \\
\text { children in the WA population aged } 0-18 \\
\text { years (approximately } 6 \% \text { ). }\end{array}$ & $\begin{array}{l}\text { Presenta- } \\
\text { tion at the } \\
\text { Emergency } \\
\text { Department }\end{array}$ & $\begin{array}{l}\text { Fairly effective. } \\
\text { Several risk factors } \\
\text { were identified for } \\
\text { abused children. } \\
\text { However, local injury } \\
\text { codes were used } \\
\text { instead of ICD-10. } \\
\text { Thus, data could not } \\
\text { be compared } \\
\text { internationally. }\end{array}$ \\
\hline 10 & $\begin{array}{l}\text { Prediction of } \\
\text { child abuse risk } \\
\text { from emergency } \\
\text { department use. }\end{array}$ & $\begin{array}{l}\text { Guenther E, } \\
\text { Knight S, Olson } \\
\text { LM, Dean JM, } \\
\text { Keenan HT. }\end{array}$ & $\begin{array}{l}\text { Database: } \\
\text { January 1, 2001, and } \\
\text { December 31, 2002, } \\
\text { Utah Division of Child } \\
\text { and Family Services } \\
\text { (DCFS), birth certificate, } \\
\text { death certificate } \\
\text { and emergency } \\
\text { department state-wide } \\
\text { databases } \\
\text { Population: }\end{array}$ & $\begin{array}{l}\text { 1. Children with supported child abuse } \\
\text { have a higher use of the emergency } \\
\text { department, before diagnosis of abuse, } \\
\text { when compared with the general } \\
\text { pediatric population. } \\
\text { 2. Neither the frequency of emergency } \\
\text { department uses nor the pattern of } \\
\text { diagnoses offers sufficient specificity to } \\
\text { be useful markers of future abuse. }\end{array}$ & $\begin{array}{l}\text { Presenta- } \\
\text { tion at the } \\
\text { Emergency } \\
\text { Department }\end{array}$ & $\begin{array}{c}\text { Not effective. } \\
\text { Frequency of } \\
\text { emergency } \\
\text { department or } \\
\text { pattern of diagnosis } \\
\text { unable to predict risk } \\
\text { of abuse. }\end{array}$ \\
\hline
\end{tabular}




\section{Pediatrics \& Neonatal Biology Open Access}

\begin{tabular}{|c|c|c|c|c|c|c|}
\hline & & & $\begin{array}{l}\text { Children }<13 \text { years of age } \\
\text { - Cases }(n=9795) \\
\text { - Control }(n=9795) \\
n=884 \\
\text { Country: } \\
\text { US }\end{array}$ & & & \\
\hline 11 & $\begin{array}{l}\text { Emergency } \\
\text { department } \\
\text { attendance by } \\
\text { children at risk } \\
\text { of abuse. }\end{array}$ & $\begin{array}{l}\text { Leaman AM, } \\
\text { Holt A, } \\
\text { Ramakrishnan } \\
\text { RG. }\end{array}$ & $\begin{array}{l}\text { Database: } \\
2006 \\
\text { 1. Two child protection } \\
\text { registers in the } \\
\text { Shropshire area } \\
\text { 2. Computerized records } \\
\text { of ED attendances } \\
\text { Population: } \\
\text { Children aged 0-12 years } \\
\text { - Cases (n }=220) \\
\text { - Control (n=1950) } \\
\text { Country: } \\
\text { UK }\end{array}$ & $\begin{array}{l}\text { 1. In the } 2 \text { years before being placed on a } \\
\text { child protection register, the ED and } \\
\text { outpatient attendances of at-risk children } \\
\text { are no greater than those of an age- } \\
\text { matched control group of children } \\
\text { attending the ED for injury or illness. } \\
\text { 2. Maltreated children had more frequent } \\
\text { changes of healthcare provider. }\end{array}$ & $\begin{array}{l}\text { Presenta- } \\
\text { tion at the } \\
\text { Emergency } \\
\text { Department }\end{array}$ & $\begin{array}{l}\text { Not effective. } \\
\text { Frequency of ED visits } \\
\text { are not an effective } \\
\text { marker of child abuse. }\end{array}$ \\
\hline 12 & $\begin{array}{l}\text { Injuries in } \\
\text { children and } \\
\text { adolescents- } \\
\text { Analysis of } \\
41,330 \text { injury } \\
\text { related visits to } \\
\text { an emergency } \\
\text { department in } \\
\text { northern } \\
\text { Sweden. }\end{array}$ & $\begin{array}{l}\text { Hedström EM, } \\
\text { Bergström U, } \\
\text { Michno P. }\end{array}$ & $\begin{array}{l}\text { Database: } \\
1998 \text { - } 2008 \\
\text { Pediatric injury registry } \\
\text { of emergency department } \\
\text { in Umea }{ }^{\circ} \text { University } \\
\text { Hospital } \\
\text { Population: } \\
\text { Children aged 0-19 } \\
\text { years, n=33,781 } \\
\text { Country: } \\
\text { Northern Sweden }\end{array}$ & $\begin{array}{l}\text { 1. The rate of injury related visits to the } \\
\text { emergency department was } 110 / 1000- \\
\text { person years. } \\
2 \text {. Variations in type of injury, mechanism } \\
\text { and activity at injury in different age } \\
\text { group and sex reflected the hazards } \\
\text { associated with different periods in } \\
\text { growth. } \\
\text { 3. } 1039 \text { visits resulted from interpersonal } \\
\text { violence such as violence between peers, } \\
\text { domestic violence and neglect, with crude } \\
\text { rate of } 28(26-30) / 10,000 \text { per year. }\end{array}$ & $\begin{array}{l}\text { Presenta- } \\
\text { tion at the } \\
\text { Emergency } \\
\text { Department }\end{array}$ & $\begin{array}{l}\text { Not effective. } \\
\text { Many cases were } \\
\text { likely to be } \\
\text { underreported due to } \\
\text { reluctance to seek } \\
\text { medical } \\
\text { care and difference in } \\
\text { description of event of } \\
\text { injury at presentation. }\end{array}$ \\
\hline
\end{tabular}

Table 1: Similar emerging themes cutting across all articles included in the systematic review. 


\section{Pediatrics \& Neonatal Biology Open Access}

A summary of the emerging themes from the review is shown in Figure 2.

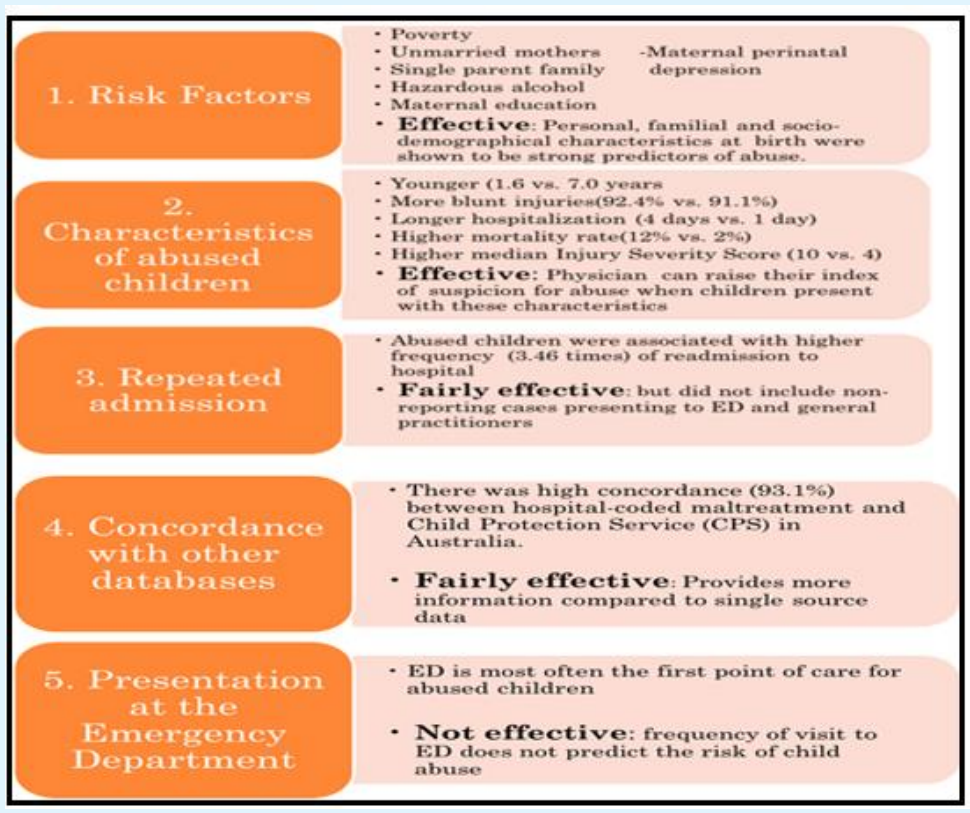

Figure 2: Flow chart of themes emerged by level of effectiveness in identifying children potentially at risk of abuse.

\section{Risk Factors}

Several articles found that certain risk factors are significantly associated with an increased risk of abuse in children. Studies in the United States (US) have shown that ethnicity was associated with increased risk of childhood injury and mortality. According to Falcone and colleagues, there was a 3.5 -fold increased risk of death from injury for African American (AA) compared to white infants and this is consistent with known race-based health disparities [11]. The study conducted by Putnam and colleagues based in California, they found that almost one-third of children born to African-American mothers were reported to Child Protective Services (CPS) during the first five years of life [12]. Children in single-parent families were documented to have an increased risk of maltreatment [12]. In contrast, 2-adult households and increasing maternal age were protective against maltreatment, thermal injuries and fractures $[13,14]$. In addition, maternal perinatal depression, maternal smoking and hazardous alcohol use were identified as risk factors for increased childhood thermal injury and poisonings [13]. These modifiable factors have implications on prevention, as children are at risk from fire caused by maternal smoking and from the violence of drunken parents [14].
Poverty (incidence in $22 \%$ of children covered by Medi-Cal) and maternal education (incidence in $\sim 20 \%$ of children born to a mother with less than a high school degree) also increased the risk of child abuse by the age of five [12]. Medi-Cal is California's Medicaid program serving low-income individuals, including: families, seniors, persons with disabilities, children in foster care, pregnant women, and childless adults with incomes below $138 \%$ of federal poverty level [15]. An Estonian study also associated mothers' unmarried marital status, non-Estonian nationality and multiplicity of pregnancy with higher risk of childhood mortality [14]. Male sex and higher birth order were associated with increased risk of injury and death in children $[13,14]$.

Most of the databases that were utilized to analyses risk factors have demonstrated some level of effectiveness in identifying risks factors associated with child neglect/abuse. Personal, familial and sociodemographical characteristics at birth were shown to be strong predictors of abuse [12]. Identification of mechanism of child injury and linkage of maternal data were fairly effective; however, no effort was made to identify child abuse based on modifiable factors including 


\section{Pediatrics \& Neonatal Biology Open Access}

perinatal depression and parental hazardous alcohol consumption $[11,13,14]$.

\section{Repeated Admission to Hospital}

According to a study in Western Australia (WA), abused children were associated with higher frequency of readmission to hospital [16]. Certain populations and age groups such as children aged $0-4$ years from rural/remote areas and indigenous children aged 5-9 years were predisposed to higher risk of second hospitalization due to interpersonal violence. A majority of interpersonal violence hospitalization among children were attributed to rape and maltreatment (73\%).

A study conducted by Powell in 2003 found that a panel of experts from social services/ social work, health services and police services agreed (consensus was defined as $75 \%$ or more of participants agreeing/ strongly agreeing) that children with frequent admissions to hospital with all tests negative was considered to be an early indicator of child abuse and neglect [17].

Based on the study done by Meuleners, et al. although documented repeated admission was effective in aiding the detection of child abuse, limitations exist through non-admitted cases presenting to the ED and general practitioners [16].

\section{Characteristics of Abused Children}

A study in the US conducted by Chang and colleagues in 2004, showed that significant characteristics in pediatric trauma service were associated with risk of abuse. Compared to non-abused cases, abused children were younger (1.6 vs. 7.0 years); complained with more blunt injuries (92.4\% vs. 91.1\%); experienced higher median Injury Severity Score (10 vs. 4) especially for head and integument injuries; stayed longer in hospital (4 days vs. 1 day) and experienced a higher mortality rate $(12 \%$ vs. 2\%) [18]. Many of them were also transferred from another institution (40.3\%). Moreover, fathers, stepfathers or male partners were the most common perpetrators of abuse (58.6\%). This Pediatric Trauma Service and its Registry was effective in detecting child abuse as physicians can raise their index of suspicion for abuse when children present with these specific characteristics [18].

\section{Concordance with Other Databases}

There was high concordance (93.1\%) between hospital-coded maltreatment and Child Protection Services (CPS) in Australia. However, being registered under CPS did not prevent child maltreatment as 85 percent of maltreatment-coded children already had recent CPS events. In addition, one-third of children who were coded as presenting for unintentional injury in hospital had prior CPS records, with 11 percent of them having a recent CPS event [19]. This highlights the possibility of abuse in children presenting with unintentional injuries. Another study in the US showed a slight increase in the incidence of hospitalized children with serious injuries due to physical abuse over 12 years. However, these results contradicted with CPS data which showed marked declining in substantiated physical abuse [20]. These contradicting findings highlight the challenges and limitations of using a single source data in tracing child abuse. Notwithstanding, the evidence suggests that detection of child abuse through concordance of databases was fairly effective.

\section{Presentation at the Emergency Department}

Four studies used ED databases for their research. Study conducted by Hedstrom and colleagues in Sweden, 1,039 ED visits by children between 1998 to 2008 were due to interpersonal violence, representing a crude rate of 28/10,000 per year; while in Western Australia (WA), 177 ED visits from 2001-2005 were due to maltreatment according to O'Donnell and colleagues [21,22]. Approximately 6 percent of the Aboriginal children population (ages between 0 to 18 years old) in WA presented to the ED with maltreatment $(24 \%)$ and intentional injury (16\%) [22]. Further, studies demonstrate that females were at higher risk of abuse compared with males [22,23]. In addition, children who were socio-economically disadvantaged had higher ED presentations due to maltreatment compared with children in higher SES groups [22]. Two studies conducted by Guenther, et al., and Leaman, et al., in 2009 and 2010 respectively concluded that the frequency of visits to ED does not predict the risk of child abuse, while another study added that the pattern of diagnoses is not a good predictor of child abuse. This is likely due to few differences in the frequency of ED visits between children who are identified as at risk of abuse and the control group [23,24]. These findings suggest that current databases relating to ED presentation are not effective in determining risk of child abuse.

\section{Discussion}

Clinical acumen, skill and diplomacy among healthcare professionals are needed in early recognition and management of child abuse [25,26]. Failure in early detection of child abuse poses risks of continuous suffering to an innocent child that might lead to permanent disability or mortality [27]. Thus, 


\section{Pediatrics \& Neonatal Biology Open Access}

comprehensive child injury databases are considered essential tools and resources to assist in detecting not only those who are abused or neglected, but to identify those at risk, and to inform the development of additional programs/resources to prevent child injury.

The first point of care for abused or neglected children is most often the clinical setting, specifically the Emergency Department (ED), in addition to general practitioners, the police and the Department of Social and Welfare (DSW). While it has been noted that cases of child abuse detected through ED could be underestimated as some would seek other healthcare services to evade detection by authorities, or hide their reason for visiting the ED $[24,28]$. EDs are often the point where first-hand information is received either from the child or their parents/caretakers. However, many generic ED databases are minimum datasets and provide insufficient data to predict risk of abuse/neglect. Thus, information keyed into the database should be thorough and accurate, while acknowledging the intricacies of detecting child abuse/neglect solely from one visit. It is important for the attending doctor to obtain a good history from the child's initial visit. Information such as risk factors, repeated admission, patterns of injuries, and concordance with other databases need to be taken into consideration.

The documentation of certain risk factors in databases or registries that should raise the index of suspicion for child abuse/neglect, and there are numerous international studies that have demonstrated that it is essential to examine and identify risk factors with the use of good data. For example, an initial examination of Child Protection Services (CPS) data showed that children of black ethnicity were more likely to present to CPS. This finding was is consistent with the findings of a prospective study in the United States (US), again, using inferior data [29]. With the use of more in-depth and robust data, and making appropriate adjustments for important factors such as socioeconomic deprivation, subsequent studies found that there were, in fact, no significant racial differences in reports of child maltreatment [30]. Poverty instead was a major risk factor in the causation of child abuse [31-33]. This could be explained by harsher parenting styles and also stress associated with socioeconomic deprivation or disadvantage [34-37].

Similarly, single parenthood and having unwed mothers were identified as risk factors in children suspected of abuse [14]. This was correlated by other studies, but these studies also suggested that maternal employment may compromise quality care-giving environment, thus putting children at risk [34,38]. Perinatal depression was also linked to increased rates of child abuse, supported by a Turkish study which found that the most common maternal psychiatric disorder leading to child abuse was depression $(5.6 \%)[39,40]$. The relationship between Munchausen syndrome by proxy in mothers with perinatal depression and child abuse should also be noted [41]. With the availability of this maternal information when children present with an injury, children at risk could be identified and targeted for intervention [40]. Another risk factor is parental alcohol use, as there is a propensity for violence to occur $[25,33,42,43]$. This is evidenced by the involvement of a majority (54.7\%) of maternal alcohol abusers with the CPS, with 42 percent of children removed from their care [44]. Substance abuse is also another risk factor, where one or both parents use illegal substance. Children whose parents abuse substances are almost three times more likely to be abused and four times more likely to be neglected than other children $[37,45,46]$.

In addition, non-nationality is associated with increased risk of child abuse. This is explained by the tensions due to differences in cultural orientation between parent and child, leading to intergenerationalintercultural conflict [47]. Moreover, the differences in punishment methods for example, corporal punishment in immigrant families has been shown to contribute to the higher prevalence of child physical abuse [48]. However, the paucity of available data regarding the child's immigration status warrants further research to understand the associations between these factors and risk of abuse/neglect [47].

Apart from the above risk factors, repeated admission is another predictor of potential child abuse. Chronic child abuse and recurrence of abuse are not uncommon. Many children re-enter the CPS after the first incidence of abuse within two to three years. A National Child Abuse and Neglect Data System (NCANDS) study estimated that 22 percent of abused children were re-reported within 24 months [49]. Another study also reported that the recurrence rate of abuse was 47 percent at the end of 36 months and 62 percent by 7.5 years after initial referral [50]. Thus, repeated admission noticed from hospital admission database should raise the alarm about possible child abuse.

Furthermore, based on the evidence, children who present with certain characteristics of the children and the injuries should be assessed for risk of abuse. The distribution of abuse is skewed toward the younger age group, most probably due to their vulnerability and 


\section{Pediatrics \& Neonatal Biology Open Access}

inability to flee $[18,37]$. Also, presentation of more blunt injuries might be attributed to accessibility of blunt objects at home. Several studies commented that superficial injuries and bruising were found in abused children [51-53]. Injury from abuse is often located at the head region due to child's small stature which makes the head the closest part to an adult's hand, followed by the skin, which is perceived as a lesser vital organ to harm.

Finally, the current findings suggest that integration between health and welfare system data is crucial in early detection of child abuse and neglect. While neither system captures the cases completely, concordance of databases provides insight into the potentially undetected cases. Many supportive studies showed good linkage of hospital records with CPS data. An Australian study found nearly all children with hospital assigned abuse codes (93.1\%) had registered under CPS (16). Another study in Missouri also demonstrated 88 percent concordance between child abuse hospitalization data with CPS data [54]. The number of non-concordant cases, however small, necessitates efforts in improving the linkage to achieve 100 percent concordance.

The present review has several limitations. First, as child injury databases were reviewed, the focus was only on detection of physical abuse instead of other forms of abuse such as neglect, sexual and emotional abuse, which can be equally harmful to the child. Second, the articles reviewed were mostly from developed countries which had more advanced health systems and thorough child injury databases. Thus, the findings might not be representative of the global population of child injury cases. Third, since articles reviewed came from different countries, different diagnostic criteria of injury were applied. Although International Classification of Diseases, Ninth Revision, Clinical Modification (ICD-9-CM) codes were commonly used in diagnosis of child abuse from injury, the accuracy might vary. A previous study has shown variability in diagnosis of abuse when the same child abuse case was reviewed by physicians [55]. Fourth, the exclusion of grey literature might omit potentially important unpublished information and recent data which restricted the literature thus not being able to provide a more complete view of available evidence.

\section{Conclusion}

Existing studies showed that there are still limitations in databases for identifying children at risk of abuse. A centralized system which is able to identify and flag potentially abused children based on risk factors, characteristics of abused children, frequency of repeated admission and presentation to the ED is recommended. The set-up of a standardized and integrated database not only among hospitals, but also between hospitals and other relevant agencies, would enable swift collaboration between healthcare professionals and welfare agencies from the first point of contact. The resulting efficiency will translate to better detection and subsequently, more lives of children can save. This is in accordance to Malaysia's commitment to the Millennium Developmental Goals (MDGs) and the Child's Rights Convention (CRC) to provide better, safer and more sustainable environment for our children to grow.

\section{References}

1. Louwers EC, Affourtit MJ, Moll HA, de Koning HJ, Korfage IJ (2010) Screening for child abuse at emergency departments: a systematic review. Arch Dis Child 95(3): 214-218.

2. Ham-Baloyi WT, Jordan P (2016) Systematic review as a research method in post-graduate nursing education. Health SA Gesondheid 21: 120-128.

3. Merriam-Webster (2017) Definition of DATABASE.

4. Noraziani K, Nurul'Ain M, Ekhab S, Drak B, Ezat WPS, et al. (2013) An overview of electronic medical record implementation in healthcare system: Lesson to learn. World Appl Sci J 25(2): 323-332.

5. Mohan J, Yaacob RRR (2004) The Malaysian Telehealth Flagship Application: a national approach to health data protection and utilisation and consumer rights. Int J Med Inf 73(3): 217-227.

6. Sharmini S, Jamaiyah H, Jaya Purany SP (2010) CrossSectional Survey of Multi-Centre Patient Registries in Malaysia. Malays Fam Physician 5(1): 13-18.

7. Tursz A, Crost M, Gerbouin-Rérolle P, Cook JM (2010) Under ascertainment of child abuse fatalities in France: Retrospective analysis of judicial data to assess underreporting of infant homicides in mortality statistics. Child Abuse Negl 34(7): 534-544.

8. Bailhache M, Leroy V, Pillet P, Salmi LR (2013) Is early detection of abused children possible?: A systematic review of the diagnostic accuracy of the identification of abused children. BMC Pediatr 13: 202.

9. Flanagan NM, MacLeod C, Jenkins MG, Wylie R (2002) The Child Protection Register: A tool in the accident 


\section{Pediatrics \& Neonatal Biology Open Access}

and emergency department?. Emerg Med J 19(3): 229-230.

10. Child Welfare Information Gateway (2018) Establishment and Maintenance of Central Registries for Child Abuse Reports.

11. Falcone RA Jr, Brown RL, Garcia VF (2007) The epidemiology of infant injuries and alarming health disparities. J Pediatr Surg 42(1): 172-176.

12. Putnam-Hornstein E, Webster D, Needell B, Magruder J (2011) A Public Health Approach to Child Maltreatment Surveillance: Evidence from a Data Linkage Project in the United States. Child Abuse Rev 20(4): 256-273.

13. Orton E, Kendrick D, West J, Tata LJ (2012) Independent Risk Factors for Injury in Pre-School Children: Three Population-Based Nested CaseControl Studies Using Routine Primary Care Data. PLOS ONE 7(4): 1-8.

14. Tiikkaja S, Rahu K, Koupil I, Rahu M (2009) Maternal social characteristics and mortality from injuries among infants and toddlers in Estonia. J Epidemiol Community Health 63(8): 633-638.

15. Medi-Cal (2017) In: Wikipedia.

16. Meuleners LB, Lee AH, Hendrie D (2009) A population-based study of repeat hospital admissions due to interpersonal violence for children aged 0-9 years. Paediatr Perinat Epidemiol 23(3): 239-244.

17. Powell C (20003) Early indicators of child abuse and neglect: a multi-professional Delphi study. Child Abuse Review 12(1): 25-40.

18. Chang DC, Knight V, Ziegfeld S, Haider A, Warfield D, et al. (2004) The tip of the iceberg for child abuse: the critical roles of the pediatric trauma service and its registry. J Trauma 57(6): 1189-1198.

19. McKenzie K, Scott D, Fraser JA, Dunne MP (2012) Assessing the concordance of health and child protection data for "maltreated" and "unintentionally injured" children. Inj Prev 18(1): 50-57.

20. Leventhal JM, Gaither JR (2012) Incidence of Serious Injuries Due to Physical Abuse in the United States: 1997 to 2009. Pediatrics 130(5): 847-852.

21. Hedström EM, Bergström U, Michno P (2012) Injuries in children and adolescents--analysis of 41,330 injury related visits to an emergency department in northern Sweden Injury 43(9): 1403-1408.

22. O’Donnell M, Nassar N, Jacoby P, Stanley F (2012) Western Australian emergency department presentations related to child maltreatment and intentional injury: population level study utilising linked health and child protection data. J Paediatr Child Health 48(1): 57-65.

23. Guenther E, Knight S, Olson LM, Dean JM, Keenan HT (2009) Prediction of child abuse risk from emergency department use. J Pediatr 154(2): 272-227.

24. Leaman AM, Holt A, Ramakrishnan RGP (2010) Emergency department attendance by children at risk of abuse. Emerg Med J EMJ 27(1): 26-28.

25. Barth RP (2009) Preventing Child Abuse and Neglect with Parent Training: Evidence and Opportunities. Future Child 19(2): 95-118.

26. Burdick WP, Davidson SJ (1985) Expansion of emergency medicine's responsibilities for preclinical education of medical students. Ann Emerg Med 14(2): 131-133.

27. Petersen AC, Joseph J, Feit M (2014) New Directions in Child Abuse and Neglect Research. National Academies Press (US).

28. Paavilainen E1, Merikanto J, Astedt-Kurki P, Laippala $P$, Tammentie $T$ et al. (202) Identification of child maltreatment while caring for them in a university hospital. Int J Nurs Stud 39(3): 287-294.

29. Flaherty EG, Sege RD, Griffith J, Price LL, Wasserman R, Slora E, et al. (2008) From Suspicion of Physical Child Abuse to Reporting: Primary Care Clinician Decision-Making. Pediatrics 122(3).

30. Drake B, Lee SM, Jonson-Reid M (2009) Race and child maltreatment reporting: Are Blacks overrepresented?. Child Youth Serv Rev 31(3): 309316.

31. Freisthler B, Needell B, Gruenewald PJ (2005) Is the physical availability of alcohol and illicit drugs related to neighborhood rates of child maltreatment?. Child Abuse Negl 29(9): 1049-1060.

32. Woodruff K, Lee B (2011) Identifying and predicting problem behavior trajectories among pre-school children investigated for child abuse and neglect. Child Abuse Negl 35(7): 491-503. 


\section{Pediatrics \& Neonatal Biology Open Access}

33. Freisthler B, Merritt DH, LaScala EA (2006) Understanding the Ecology of Child Maltreatment: A Review of the Literature and Directions for Future Research. Child Maltreat 11(3): 263-280.

34. Berger LM (2004) Income, family structure, and child maltreatment risk. Child Youth Serv Rev 26(8): 725748.

35. Steinberg LD, Catalano R, Dooley D (1981) Economic antecedents of child abuse and neglect. Child Dev 52(3): 975-985.

36. Trickett PK, Aber J. Lawrence, Carlson V, Cichettii D (1991) Relationship of socioeconomic status to the etiology and developmental sequelae of physical child abuse. Dev Psychol 27(1): 148-158.

37. Centers for Disease Control (2016) Risk and Protective Factors: Child Abuse and Neglect.

38. Guterman NB, Lee Y (2005) The Role of Fathers in Risk for Physical Child Abuse and Neglect: Possible Pathways and Unanswered Questions. Child Maltreat 10(2): 136-149.

39. Çengel-Kültür E, Çuhadaroglu-Çetin F, Gökler B (2007) Demographic and clinical features of child abuse and neglect cases. Turk J Pediatr 49(3): 256262.

40. Windham AM, Rosenberg L, Fuddy L, McFarlane E, Sia $C$, et al. (2004) Risk of mother-reported child abuse in the first 3 years of life. Child Abuse Negl 28(6): 645667.

41. Rosenberg DA (1987) Web of deceit: A literature review of Munchausen syndrome by proxy. Child Abuse Negl 11(4): 547-563.

42. Davies EA, Jones AC (2013) Risk factors in child sexual abuse. J Forensic Leg Med 20(3): 146-150.

43. Murphy JM, Jellinek M, Quinn D, Smith G, Poitrast FG, et al. (1991) Substance abuse and serious child mistreatment: Prevalence, risk, and outcome in a court sample. Child Abuse Negl 15(3): 197-211.

44. Conners NA, Bradley RH, Mansell LW, Liu JY, Roberts TJ, et al. (2004) Children of Mothers with Serious Substance Abuse Problems: An Accumulation of Risks. Am J Drug Alcohol Abuse 30(1): 85-100.

45. Foster SE, Macchetto ML (1999) Providing Safe Haven: The Challenge to Family Courts in Cases of
Child Abuse and Neglect by Substance-Abusing Parents. J Health Care Law Policy 3(1): 44-68.

46. Children's Bureau (2015) Child Maltreatment. Washington, DC: US Department of Health \& Human Services pp: 1-248.

47. Johnson MA (2007) The social ecology of acculturation: Implications for child welfare services to children of immigrants Child Youth Serv Rev 29(11): 1426-1438.

48. Chang J, Rhee S, Weaver D (2006) Characteristics of child abuse in immigrant Korean families and correlates of placement decisions. Child Abuse Negl 30(8): 881-891.

49. Fluke JD, Shusterman GR, Hollinshead DM, Yuan YY (2008) Longitudinal Analysis of Repeated Child Abuse Reporting and Victimization: Multistate Analysis of Associated Factors. Child Maltreat 13(1): 76-88.

50. Drake B, Jonson-Reid M, Sapokaite L (2006) Rereporting of child maltreatment: Does participation in other public sector services moderate the likelihood of a second maltreatment report?. Child Abuse Negl 30(11): 1201-1226.

51. Scott D, Walker S, Fraser JA, Valmuur K (2014) A needle in a haystack: The use of routinely collected emergency department injury surveillance data to help identify physical child abuse. Int J Inj Contr Saf Promot 21(3): 227-235.

52. Martindale J, Swenson A, Coffman J, Newton AW, Lindberg DM (2014) Recurrent concerns for child abuse: Repeated consultations by a subspecialty child abuse team. Child Abuse Negl 38(7): 1259-1266.

53. Spivey MI, Schnitzer PG, Kruse RL, Slusher P, Jaffe DM (2009) Association of Injury Visits in Children and Child Maltreatment Reports. J Emerg Med 36(2): 207 214.

54. Schnitzer PG, Slusher P, Van Tuinen M (2004) Child maltreatment in Missouri: Combining data for public health surveillance. Am J Prev Med 27(5): 379-384.

55. Lindberg DM, Lindsell CJ, Shapiro RA (2008) Variability in Expert Assessments of Child Physical Abuse Likelihood. Pediatrics 121(4): 945-953.

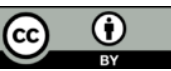

